\title{
Honoré de Balzac, Fisiologia del matrimonio. Meditazioni di filosofia eclettica sulla felicità e l'infelicità coniugale
}

\section{Marco Stupazzoni}

\section{(2) OpenEdition \\ Journals}

Edizione digitale

URL: http://journals.openedition.org/studifrancesi/5378

DOI: $10.4000 /$ studifrancesi. 5378

ISSN: 2421-5856

\section{Editore}

Rosenberg \& Sellier

\section{Edizione cartacea}

Data di pubblicazione: 1 dicembre 2016

Paginazione: 543

ISSN: 0039-2944

\section{Notizia bibliografica digitale}

Marco Stupazzoni, « Honoré de Balzac, Fisiologia del matrimonio. Meditazioni di filosofia eclettica sulla felicità e l'infelicità coniugale », Studi Francesi [Online], 180 (LX | III) | 2016, online dal 01 janvier 2017, consultato il 17 septembre 2020. URL : http://journals.openedition.org/studifrancesi/5378 ; DOI : https://doi.org/10.4000/studifrancesi.5378

Questo documento è stato generato automaticamente il 17 settembre 2020.

\section{cc) (†) $\odot$}

Studi Francesi è distribuita con Licenza Creative Commons Attribuzione - Non commerciale - Non opere derivate 4.0 Internazionale. 


\title{
Honoré de Balzac, Fisiologia del matrimonio. Meditazioni di filosofia eclettica sulla felicità e l'infelicità coniugale
}

\author{
Marco Stupazzoni
}

\section{NOTIZIA}

HONORÉ DE BALZAC, Fisiologia del matrimonio. Meditazioni di filosofia eclettica sulla felicità e l'infelicità coniugale, traduzione di Emilio Faccioli, Roma, Ellint, 2015, «Raggi», 319 pp.

Pubblicata, in prima edizione, nel dicembre 1829, la Physiologie du mariage ha goduto, almeno sino alla prima metà del secolo scorso, in Italia, di un'ampia e diffusa fortuna editoriale e critica. Nella collana «Raggi» delle Edizioni Lint, è riproposta l'ormai classica traduzione che, di questo studio analitico balzachiano, ha fornito Emilio Faccioli quasi trent'anni or sono, nel 1987, per la collana «Gli Struzzi» dell'editore Giulio Einaudi di Torino. 